\section{The Cephalonia, Ionian Sea (Greece), sequence of strong earthquakes of January-February 2014: a first report}

\author{
Gerassimos A. Papadopoulos, \\ Vassilios K. Karastathis, ${ }^{1}$ \\ loannis Koukouvelas,, ${ }^{2}$ Maria Sachpazi, ${ }^{1}$ \\ loannis Baskoutas, ${ }^{1}$ \\ Gerassimos Chouliaras, \\ Apostolos Agalos, ${ }^{1}$ Eleni Daskalaki, \\ George Minadakis, ${ }^{1}$ Alexandra Moshou, ${ }^{1}$ \\ Aggelos Mouzakiotis,' \\ Katerina Orfanogiannaki, ${ }^{1}$ \\ Antonia Papageorgiou, \\ Dimitrios Spanos, ${ }^{2}$ loanna Triantafyllou ${ }^{1}$ \\ ${ }^{1}$ Institute of Geodynamics, National \\ Observatory of Athens; ${ }^{2}$ Department of \\ Geology, University of Patras, Greece
}

\section{Abstract}

On 26.1.2014 and 3.2.2014 two strong earthquakes of $\mathrm{M}_{\mathrm{w}} 6.0$ and $\mathrm{M}_{\mathrm{w}} 5.9$ ruptured the western Cephalonia Isl., Ionian Sea (Greece), at the SSW-wards continuation of the Lefkada segment of the Cephalonia Transform Fault Zone (CTFZ), causing considerable damage and a variety of ground failures. High-precision relocation of the aftershocks implies that the seismogenic layer was of $35 \mathrm{~km}$ in length (L) striking NNE-SSW, of $10 \mathrm{~km}$ maximum in width and $15 \mathrm{~km}$ in thickness. Two aftershock spatial clusters were revealed at north $\left(L_{I} \sim 10\right.$ $\mathrm{km})$ and at south $\left(L_{2} \sim 25 \mathrm{~km}\right)$. However, no time correlation was found between the two clusters and the two strong earthquakes. Fitting the temporal evolution of aftershocks to the Omori-law showed slow aftershock decay. Fault plane solutions produced by moment tensor inversions indicated that the strong earthquakes as well as a plenty of aftershocks $\left(M_{w} \geq 4.0\right)$ were associated with dextral strikeslip faulting with some thrust component and preferred fault planes striking about NNE-SSW. Average fault plane parameters obtained for the three largest events are: strike $21( \pm 2)^{0}$, dip $65.5( \pm 3)^{0}$, slip $173( \pm 3)^{0}$. Broadband $P$-wave teleseismic records were inverted for understanding the rupture histories. It was found that the earthquake of 26.1.2014 had a complex source time function with c. $62 \mathrm{~cm}$ maximum slip, source duration of $\sim 12 \mathrm{~s}$ and downwards rupture. Most of the slip was concentrated on a $13 \times 9 \mathrm{~km}$ fault rupture. The earthquake of 3.2.2014 had a relatively simple source time function related with one big patch of slip with maximum slip c. $45 \mathrm{~cm}$, with $10 \mathrm{~s}$ source dura- tion. The rupture was directed upwards which along with the shallow focus $(\sim 5 \mathrm{~km})$ and the simple source time function may explain the significantly larger $(0.77 \mathrm{~g})$ PGA recorded with the second earthquake with respect to the one recorded $(0.56 \mathrm{~g})$ with the first earthquake. Most of the slip was concentrated on a $12 \times 6 \mathrm{~km}$ fault rupture. Maximum seismic intensity $\left(I_{m}\right)$ of level VII and VIII to VIII+ was felt in Lixouri town and the nearby villages from the first and the second earthquake, respectively. The rupture histories and the increased building vulnerability after the damage caused by the first shock may account for the larger $I_{m}$ caused by the second shock. However, the ground failures area of the second earthquake was nearly half of that of the first earthquake, which is consistent with the faster attenuation of ground acceleration away from the meizoseismal area caused by the second earthquake with respect to the first one. From that the 2014 earthquakes ruptured on land western Cephalonia we suggested to revise the CTFZ geometry in the sense that the Lefkada CTFZ segment does not terminates offshore NW Cephalonia but extends towards SSW in western Cephalonia.

\section{Introduction}

During January and February 2014 a sequence of strong earthquakes ruptured the western Cephalonia Isl., Ionian Sea, Greece (Figures 1 and 2), causing social unrest, remarkable damage, and several types of ground failures. According to preliminary determinations of the Institute of Geodynamics, National Observatory of Athens (NOAGI), the first strong earthquake of $\mathrm{M}_{\mathrm{L}} 5.8 / \mathrm{M}_{\mathrm{W}} 6.0$ occurred on 26 January 2014 at 13:55:42 GMT; $M_{L}$ is local magnitude, $M_{w}$ is moment magnitude. A second strong earthquake of $\mathrm{M}_{\mathrm{L}} 5.1 / \mathrm{M}_{\mathrm{w}} 5.3$ was recorded a few hours later (18:45:08), while a third strong earthquake of $\mathrm{M}_{\mathrm{L}} 5.8 / \mathrm{M}_{\mathrm{w}} 5.9$ was recorded on 3 February (3:08:44). Focal parameters of these earthquakes are listed in Table 1. Of interest is that since 22.1.2014 the first strong earthquake of 26.1.2014 was preceded by a number of about 15 small events occurring in NW Cephalonia. One may not rule out that this activity was a short foreshock sequence which, however, was not evaluated as such beforehand due to the small number of events involved. From the onset of the earthquake sequence up to writing this paper the aftershock activity was continual. For reasons of brevity, in the remaining of the paper the three strong earthquakes mentioned above are referred to as the first, second and third strong earthquake events, respectively.
Correspondence: Gerassimos A. Papadopoulos, Lofos Nymfon, Thission, PC 11810, Athens, Greece.

E-mail: papadop@noa.gr

Key words: Ionian Sea, Cephalonia Transform Fault Zone, 2014 earthquakes, relocation, focal mechanisms, strike-slip faulting, rupture histories, macroseismic intensity, ground failures.

Acknowledgements: this paper is a contribution to the EU FP7-PEOPLE-2013-ITN Project ZIP (Zooming In between Plates: deciphering the nature of the plate interface in subduction zones), contract no. 604713, and to the internal research project EARTHWARN of the Institute of Geodynamics, National Observatory of Athens, Greece. We thank the two reviewers for their constructive comments on the initial manuscript.

Received for publication: 16 April 2014.

Revision received: 13 May 2014.

Accepted for publication: 14 May 2014.

This work is licensed under a Creative Commons Attribution NonCommercial 3.0 License (CC BYNC 3.0).

(C) Copyright G.A. Papadopoulos et al., 2014

Licensee PAGEPress, Italy

Research in Geophysics 2014; 4:5441

doi:10.4081/rg.2014.5441

The Cephalonia 2014 seismic sequence is of particular interest given the very high seismicity of the area recorded in historical times as well as during the instrumental era of seismology (Table 2). In modern times, the most prominent earthquake activity was the one that ruptured eastern Cephalonia with three sequential large earthquakes occurring on 9 , 11 and 12 August 1953 with surface-wave magnitudes of $6.4,6.8$ and 7.2, respectively. The islands of Cephalonia, Ithaki and Zakynthos (Zante) were isolated while the death toll reached about 480. On 17 January 1983 a large $\left(M_{w} 7.0\right)$ earthquake ruptured offshore western Cephalonia causing no significant damage. ${ }^{1}$ of relevance to this study is also the strong $\left(\mathrm{M}_{\mathrm{w}} 6.2\right)$ earthquake of 14 August 2003 which ruptured offshore west Lefkada Isl. situated to the north of Cephalonia ${ }^{2}$ (Figure 1).

The seismicity occurring offshore Lefkada and Cephalonia islands, Ionian Sea, has been considered as being seismotectonically connected with the Cephalonia Transform Fault Zone (CTFZ), a major dextral strike-slip structure comprising the NNE-SSW trending Lefkada segment at north and the NE-SW trending Cephalonia segment at south (Figure 1)..$^{1,3-5}$ There is evidence that the seismicity of the Ionian segment of the Hellenic Arc, including Cephalonia Isl., does not fit the characteristic earthquake model, as the rest segments of the Hellenic Arc do ${ }^{6}$ Possibly this is due to that 
Table 1. Focal parameters of the three strong earthquakes of the January-February 2014 Cephalonia seismic sequence.

\begin{tabular}{|c|c|c|c|c|c|c|c|}
\hline Date & Hour, minutes, seconds & Lat $\left({ }^{\circ}\right)$ & Long $\left(^{\circ}\right)$ & $\mathrm{M}_{\mathrm{w}}$ & ML & h $(\mathrm{km})$ & Solution \\
\hline 26.01.14 & 13.55.42.7 & $\begin{array}{l}38.2190 \\
382102\end{array}$ & $\begin{array}{l}20.5322 \\
204614\end{array}$ & 6.0 & 5.8 & 16.4 & NOAGI \\
\hline 26.01 .14 & 18.45.08.3 & $\begin{array}{l}38.2282 \\
38.2514\end{array}$ & $\begin{array}{l}20.4138 \\
20.4555\end{array}$ & 5.3 & 5.1 & $\begin{array}{l}16.5 \\
12.5\end{array}$ & $\begin{array}{c}\text { NOAGI } \\
\text { RL }\end{array}$ \\
\hline 03.02 .14 & 03.08.44.7 & $\begin{array}{l}38.2462 \\
38.2734\end{array}$ & $\begin{array}{l}20.3958 \\
20.4310\end{array}$ & 5.9 & 5.7 & $\begin{array}{l}11.3 \\
4.62\end{array}$ & $\begin{array}{c}\text { NOAGI } \\
\text { RL }\end{array}$ \\
\hline
\end{tabular}

Lat, geographical latitude; Long, geographical longitude; NOAGI, preliminary determinations (http:/www.gein.noa.gr/el/seismikotita/katalogoi-seismwn; http://bbnet.gein. noa.gr/HL/database); RL, relocated epicenters in this study.

the interaction between CTFZ and western Hellenic subduction complicates the seismotectonics and controls the seismic coupling of the area. ${ }^{7,8}$ Therefore, the study of the 2014 earthquakes is expected to help substantially in understanding better the seismotectonics and geodynamics of the Ionian segment of the Hellenic Arc.

\section{Seismicity properties}

The seismicity properties of a seismic sequence, that is the distribution in the space, time and magnitude domains, may provide useful information for understanding the process of earthquake generation and to compare with other seismic sequences. In this study we used an earthquake catalogue which covers one-month period that is from the first strong earthquake occurrence up to 25.2.2014 inclusive.

Preliminary focal parameters of the Cephalonia seismic sequence were manually determined by NOAGI on the basis of $P$ and $S$ arrival data collected from the HUSN (Hellenic Unified Seismological Network; http://www. gein.noa.gr/en/networks/husn) as well as from portable stations installed in Cephalonia 2-3 days after the first strong earthquake (Figure 2). However, due to the large number of aftershock events the preliminary earthquake catalogue was initially incomplete since only relatively larger events of magnitude $>3$ were analyzed. The catalogue was completed by the NOAGI staff only gradually, a process that was still lasting until writing this paper. Since the catalogue completeness is of particular importance to seismicity studies, we constructed a catalogue based on the automatic solutions produced by NOAGI (http://bbnet. gein.noa.gr/HL/seismicity/catalogues/automatic-alerts).

\section{Epicentral distribution of earth- quakes}

The cloud of aftershock epicenters of the 14 August 2003 Lefkada mainshock $\left(\mathrm{M}_{\mathrm{w}} 6.2\right)^{2}$ is illustrated in Figure 1 along with the epicen-
Table 2. List of some important historical earthquake events that occurred in Cephalonia Isl. Parameters taken from Papazachos and Papazachou. ${ }^{3}$

\begin{tabular}{lcccccc} 
Year & Month & Day & Long & Lat & Im & M \\
1469 & Spring & - & 38.30 & 20.50 & $9-10$ & 7.2 \\
1636 & 09 & 30 & 38.10 & 20.30 & 9 & 7.2 \\
\hline 1638 & 07 & 16 & 38.20 & 20.40 & 8 & 6.4 \\
1767 & 07 & 11 & 38.20 & 20.30 & 10 & 7.2 \\
\hline 1867 & 02 & 04 & 38.20 & 20.40 & 10 & 7.2 \\
1912 & 01 & 24 & 38.10 & 20.80 & 10 & 6.8 \\
\hline 1953 & 08 & 09 & 38.50 & 20.70 & 8 (Ithaki) & 6.4 \\
1953 & 08 & 11 & 38.10 & 20.60 & 9 & 6.8 \\
\hline 1953 & 08 & 12 & 38.30 & 20.80 & 10 & 7.2 \\
\hline
\end{tabular}

Long, geographical longitude; Lat, geographical latitude; Im, maximum intensity; M, magnitude.

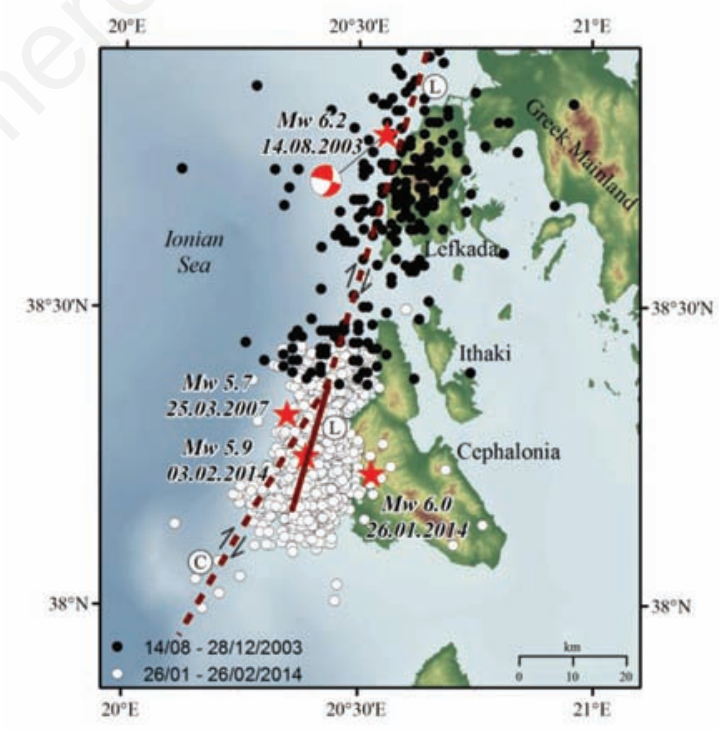

Figure 1. Spatial distributions of the Lefkada 2003 (solid circles) and Cephalonia 2014 (open circles) aftershock sequences for the time periods from 14.8.2003 to 22.9.2003 and from 26.1.2014 to 25.2.2014, respectively (data from NOAGI: http://www.gein.noa.gr/el/seismikotita/katalogoi-seismwn). Red stars show preliminary locations of the strongest earthquakes involved in the two sequences as well as the strong earthquake of 25.3.2007 which ruptured the NW part of Cephalonia (moment-magnitudes, $\mathbf{M}_{\mathrm{w}}$, as determined by NOAGI: http://bbnet.gein.noa.gr/HL/database). Beach-ball indicates the focal mechanism of the 14.8.2003 Lefkada mainshock (Harvard CMT: http://www.seismology. harvard. edu/ CMTsearch.html). Dashed lines show the geometry of the CTFZ as proposed by others with $\mathrm{L}$ and $\mathrm{C}$ corresponding to the Lefkada and Cephalonia segments, respectively. ${ }^{5}$ Thick line represents the SSW-wards extention of the Lefkada segment as proposed in this paper (see Discussion). Arrows indicate relative strike-slip motion. 
ters of the Cephalonia 2014 sequence. One may observe that the 2014 aftershock cloud, trending NNE-SSW and occupying the western part of Cephalonia, is a continuation towards SSW of the 2003 Lefkada aftershock area. Although the manual analysis provides a catalogue with better epicentral accuracy with respect to the automatic catalogue, this general picture does not change with the use of the manual catalogue as shown by the relocated aftershocks presented later.

Preliminary event locations produced manually in the NOAGI catalogue (Figure 1) are based on determinations calculated with the use of a regional 1D model of seismic wave velocities. With the aim to improve location accuracy, $P$ and $S$ arrival data were re-collected and a relocation procedure was applied by adopting a local $2 \mathrm{D}$ velocity model ${ }^{9}$ which is a modification of the one proposed by others. ${ }^{10}$ The relocated earthquake events (Figure 3) show a more compact horizontal projection and verifies that the aftershock sequence covers only the western part of Cephalonia trending from NNE to SSW at a length of about 35 $\mathrm{km}$ and maximum lateral width of c. $10 \mathrm{~km}$. This picture has important seismotectonic implications. In fact, previous suggestions considered that the Cephalonia segment of the CTFZ strikes offshore western Cephalonia based mainly on bathymetry and on some not well-determined earthquake locations. ${ }^{1,4,5}$

With the relocation applied the foci of the three strong earthquakes shifted at shallower depths, while the first strong earthquake shifted towards WNW with respect to the preliminary determinations (Table 1). The thickness of the seismogenic layer does not exceed 16 $\mathrm{km}$. The epicentral distribution reveals that the aftershock activity developed in two clusters. The first is small being of a length on the order of $10 \mathrm{~km}$ and occupying the north side of the entire aftershock cloud. The other extends in the central and south sides, thus leaving an apparent spatial gap between the two clusters. A possible explanation is that the area of the 2014 gap had already ruptured by the strong ( $\mathrm{M}_{\mathrm{w}}$ 5.5) earthquake of 25.3.2007 (Figure 1). Since no temporal relation was found between these two clusters and the occurrence of the strong events of 26 January and 3 February 2014, we suggest that the presence of the two clusters deserves further examination from the seismotectonic point of view. Besides, the possible foreshock activity that preceded the first strong earthquake of 26.1.2014 since 22.1.2014 was recorded exactly in the area of the north (small) aftershock cluster, which adds more interest as regards the seismotectonic role of this cluster.

\section{Time distribution of earthquakes}

By the end of $19^{\text {th }}$ century it was shown ${ }^{11}$ that the number of aftershocks following strong mainshocks decay with time following power-law mode, the so-called Omori law, with exponent which theoretically is $k=1$. We implemented the modified Omori-law introduced later ${ }^{12}$ and modeled the time distribution of aftershocks that followed the first and the third strong earthquakes as well as the aftershocks involved in the entire one-month period (Figure 4). It is quite characteristic that low $k$ values were found. This implies that a slow aftershock process characterized the
Cephalonia 2014 sequence, that is for a given magnitude range and time unit the aftershock number was small as compared to other sequences. For example, in the Lefkada 2003 sequence $k=1.24$ was found. ${ }^{2}$ Although the result is only preliminary, we do not expect to get drastically different results by using a final earthquake catalogue.

\section{Magnitude distribution of earthquakes}

Since the introduction of the pioneering earthquake magnitude-frequency relationship $^{13}$ it has been verified that the seismicity in global, regional, local scales and in mines, as well as the material fractures in laboratory experiments follow a power-law which is known as Gutenberg-Richter $(G-R)$ relationship: $\log N=a-b M$, where $N$ is the incremental or the cumulative number of events, $M$ is earthquake magnitude and $a, b$ parameters determined by the data. Theoretically $b=1$, but this parameter deviates from unity depending on the style of seismicity, material heterogeneity and stress distribution. The so-called $b$ value is also quite sensitive to the data completeness. In aftershock sequences the parameter $b$ usually increases with respect to the $b$ value of the background seismicity in the same area.

Using the NOAGI earthquake catalogue for the background seismicity extending from 1.1.2011 up to 26.1.2014 just prior the occurrence of the first strong Cephalonia earthquake, from the $G-R$ diagram we found magnitude completeness threshold $M_{c}=2.20$ and $b=0.99 \pm 0.11$. However, $M_{c}=2.80$ was calculated

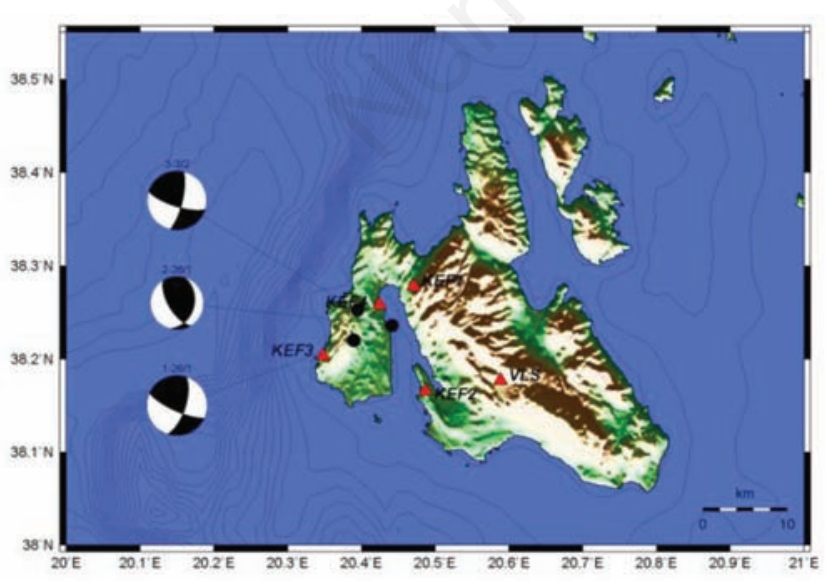

Figure 2. Focal mechanisms produced by NOAGI (http://bbnet.gein.noa.gr/HL/database) for the three strongest earthquakes are marked in chronological order by 1,2,3. Key for seismograph stations: VLS=permanent NOAGI station operating in the frame of HSUN; KEF1-4=the four portable stations installed in Cephalonia on 28 and 29 January 2014.
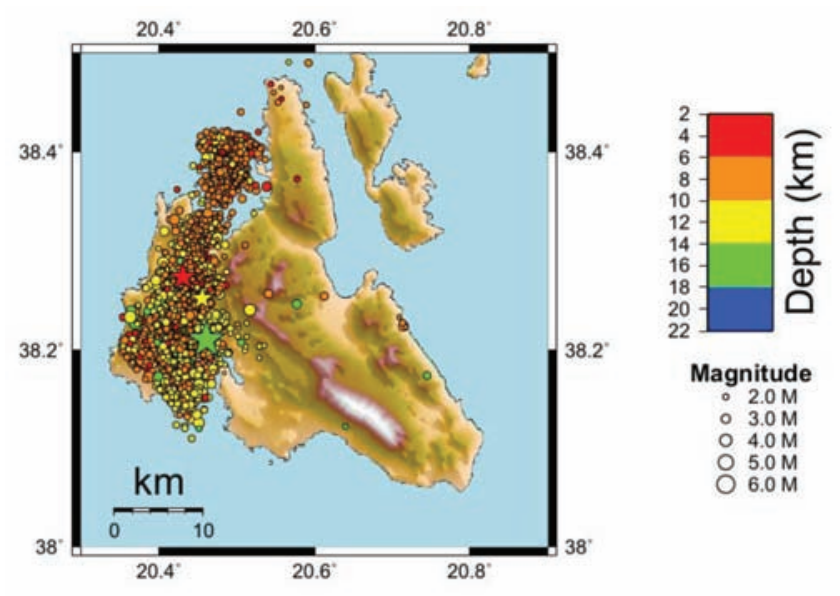

Figure 3. The one-month relocated Cephalonia seismic sequence of 2014. Star symbol key: green, yellow, red represent the three strong earthquakes of 26.1.2014 (13:55:43), 26.1.2014 (18:45:08) and 3.2.2014 (3:08:45), respectively. 
for the one-month aftershock period, indicating that several aftershock events of relatively low magnitude are missing from the catalogue used, a well-known problem with aftershock sequences. Therefore, comparing the $G-R$ relationships for joint $M_{c}=2.80, b=1.18 \pm 0.25$ and $b=0.79 \pm 0.08$ were determined for the background seismicity and the one-month aftershock sequence, respectively (Figure 5). All calculations of the $b$-value were performed with the maximum likelihood method.

The $b$-value found for the background seismicity is absolutely normal as it falls very close to unity. On the other hand, the drop of the $b$ value is not expected for an aftershock sequence. However, the Cephalonia aftershock sample examined here is not typical in the sense that after the strong earthquake of 26.1.2014 another equally strong earthquake occurred on 3.2.2014, thus contributing substantially to the drop of the parameter $b$. One may also argue that the activity that occurred after the strong earthquake of 26.1.2014 but before the one of 3.2.2014 were foreshocks of the later. If this were true then a drop of the bvalue would be expected. In any case, the results presented here are preliminary and certainly a more thorough investigation of the $b$ variation is needed when a final earthquake catalogue will be available.

\section{Earthquake focal mechanisms}

The examination of fault plane solutions have shown that the preferred fault plane of the 2003 Lefkada mainshock was characterized by the next principal parameters: strike
$13 \%$ dip $84 \%$ rake $172^{\circ}$, while the faulting was dextral strike-slip with small thrust component (e.g. Harvard, http://www.globalcmt.org; USGS; http://earthquake.usgs.gov/earthquakes/eqarc hives/year/2003/2003_08_14_mt.php).

This solution is consistent with the ones obtained by teleseismic wave modelling. ${ }^{14} \mathrm{We}$ assumed that the strong $\left(\mathrm{M}_{\mathrm{W}} 5.7\right)$ earthquake of 25.3.2007 (Figure 1) was similar to the 2003 one in both the faulting style and the preferred fault as it comes out from the fault plane solution $\left(38^{\circ} / 90^{0} / 172^{0}\right) .{ }^{15}$ To determine fault-plane solutions for the 2014 earthquake sequence a methodology and appropriate software implementing the moment tensor inversion was applied. ${ }^{16}$ The method calculates synthetic seismograms directly compared with the observed ones for a given velocity structure. A reflectivity method ${ }^{17}$ implemented appropriately $^{16}$ was applied to determine the Green's Functions. Initial inversions were performed at a depth interval of $5 \mathrm{~km}$ followed by a finer one every 1-2 km around the depth that exhibited the lowest misfit. Regional data of five, 3 component broadband stations, belonging to the HUSN and situated at different azimuth coverage and epicentral distances less than $3^{\circ}$ were selected and analyzed. The preparation of the data included deconvolution of instrument response and afterwards the velocity was integrated to displacement. Finally the horizontal components were rotated to radial and transverse ones. Then the long period part of the signal was introduced to perform inversion. After several attempts our analysis was implemented using a seismic wave velocity model considered as the most appropriate one for the area under study. ${ }^{10}$

A band-pass filter was applied in both the observed waveforms and the synthetics. In all inversions we used a fixed waveform length of $70 \mathrm{~s}$. The results of the inversion indicated that inverting waveforms longer that $70 \mathrm{~s}$ resulted in higher misfits. The quality of the results of moment tensor solutions can be evaluated by considering the average misfit and the compensated linear vector dipole (CLVD). For each solution there is a quality code $^{18}$ that ranges from $A$ to $D$ for the minimum misfit and from 1 to 4 for the percentage of CLVD.

Following the above methodology focal mechanisms of 40 earthquake events occurring from 26.01.2014 to 05.03.2014 were produced as illustrated in Figure 6 and listed in Appendix. The solutions obtained are in general consistent of each other as well as with solutions produced by other institutes for the stronger events (e.g. see CMT Harvard solutions at the end of Appendix). A statistics regarding our solutions for Plane 1 (Appendix), which has been adopted as the preferred fault plane, indicates that the ranges of strike, dip and rake are $4^{\circ}-30^{\circ}, 60^{\circ}-80^{\circ}$ and $159^{\circ}-180^{\circ}$, respectively. As regards the three largest events we got average parameters as next: strike $21( \pm 2)^{0}$, dip $65.5( \pm 3)^{0}$, slip $173( \pm 3)^{0}$. Our results imply that the predominant faulting process during the Cephalonia 2014 earthquake sequence was dextral strikeslip with small thrust component. However, in some instances, which do not include the three largest events, the thrust component was significant. The strike of faulting was about NNE being around $21^{0}$ in the largest events, while the dip deviates from the vertical.

The 2014 earthquake sequence occurred at the westernmost edge of HUSN, which results to the lack of Greek stations at the west of

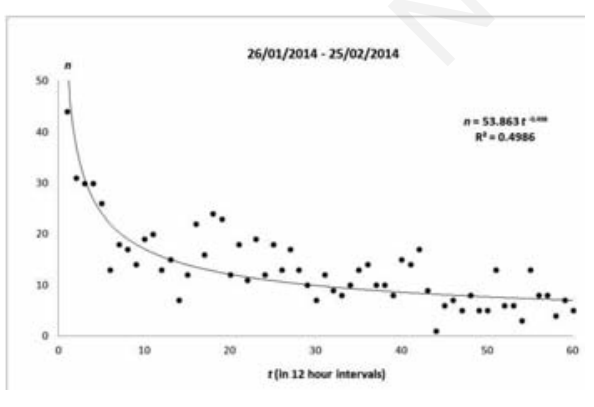

Figure 4. Power-law decay with time, $t$, of the aftershock number, $n$, for the one-month time period that followed the first strong earthquake of 26.1.2014. The exponent $k=0.498$ ( $R=$ correlation coefficient) is nearly identical with $k_{1}=0.517$ and $k_{2}=0.419$ found for the aftershock periods of the first and third strong earthquakes.

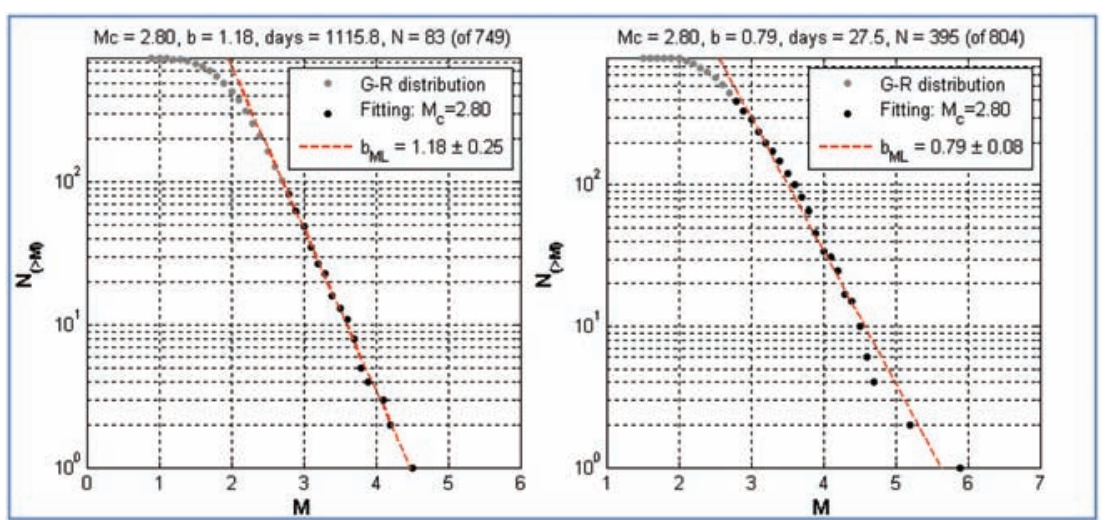

Figure 5. $G-R$ diagrams for the background seismicity (period from 1.1.2011 to 26.1.2014; left) and the one-month aftershock period (right); the mainshock of 26.1.2014 is excluded. Symbol key: $M$ is magnitude, $N$ is cumulative number of earthquakes, $b_{M L}$ is parameter b calculated by the maximum likelihood method adopting joint magnitude threshold $M_{\mathrm{c}}=2.80$. Calculations of $b_{M L}$ were performed only for $N>=M_{c}$. 
Cephalonia. Due to bad azimuthal coverage of the Greek stations, trials were made for some fault plane solutions being recalculated by adding records of Italian stations, thus extending our azimuthal coverage to the west. Trials performed for the second and third strong earthquakes showed increased misfit between the observed and synthetic seismograms, as one may expect due to the increased epicentral distances of the Italian stations used. An increase of the percentage of CLVD's was also observed, that is from $9 \%$ and $10 \%$ to $22 \%$ and $20 \%$ for the above two earthquakes, respectively. This result may indicate increased source complexity, while for the second strong earthquake of 26.1.2014 (18:45:08), the faulting style turned to predominantly thrust. On the other hand, however, these new solutions are of low quality. In fact, the solution quality, which was found $\mathrm{Al}$ in both earthquakes tested (Appendix), turned to $\mathrm{C} 2$ and $\mathrm{C} 1$, respectively. We concluded that the results obtained by the methodology applied in some instances might be influenced by the azimuthal coverage.

\section{Rupture process}

Several studies have revealed the importance of the finite fault inversion procedure to our understanding of the earthquake rupture process which may provide an accurate spatial and temporal evolution of the coseismic slip on the ruptured fault. The finite fault inversion technique has been applied using teleseismically recorded waveforms or strong motion data. ${ }^{19-25}$ Several source inversion procedures that used teleseismic waveforms provided similar slip models using also other types of data such as geodetic. ${ }^{26}$

Digital broadband records of $P$ waves at teleseismic epicentral distances between $30^{\circ}$ and $90^{\circ}$ were used to invert for rupture histories of the first and third strong Cephalonia earthquakes. The stations used are members of the global digital seismograph network (GDSN) while seismic records were downloaded through the IRIS Data Management Center. The selection of the stations permitted the best possible azimuthal coverage. The teleseismic waveforms were corrected for instrument response, integrated to displacement, band-pass filtered from 0.01 to $1 \mathrm{~Hz}$ using a Butterworth filter and finally re-sampled to 0.2 samples/s.

The finite fault inversion method ${ }^{19}$ is capable of estimating the distributions of both the spatial slip and rise time on the ruptured fault. The application starts with the discretization to a number of uniform cells (subfaults) of a rectangular fault plane. The strike, dip, rake and focal depth are inserted to produce the ele- mentary synthetics for each subfault. The followed finite-fault inversion approach does not permit the rupture velocity to change but the use of multiple time windows permits the same subfault to rupture multiple times. The amount of slip in successive time intervals for each subfault is lagged in time by the width of the source. In this way, rise time functions are constructed and are free to vary as a function of position on the fault plane. ${ }^{20}$ The subfault may fail within the maximum allowed time window.

We applied the inversion procedure using the Harvard CMT focal mechanism solutions for the first and third strong Cephalonia earthquakes (see Appendix). Many inversions were tested changing the dip of the fault and using source rupture velocity varying from 2.6 to 3.5 $\mathrm{km} / \mathrm{s}$ by inserting different fault dimensions and time lags. A velocity mode ${ }^{10}$ proposed for the area under study was used to create the subfault synthetics. The point source responses were computed with a code based on the generalized ray theory. ${ }^{27}$ The exact way these synthetics were constructed was discussed by others, ${ }^{28}$ assuming that circular rupture fronts propagate at a given rupture velocity everywhere on the assumed fault plane. The absolute size of dislocation is specified to be related to the position on the fault. The elementary synthetics are always filtered with the same filter as the data and are convolved with an attenuation operation assuming $\mathrm{t}^{*}=1 \mathrm{~s}$ for $P$ waves. The inversion approach applied also permits the rake of the fault plane to vary upon the fault. ${ }^{21}$ In this case each subfault has $n \times 2$ model parameters to change during the inversion, where $n$ is the number of time windows and 2 is for two mechanisms. For Cephalonia earthquakes the rake was left to vary from $90^{\circ}$ to $180^{\circ}$, corresponding to pure thrust and strike-slip movement, respectively. The observed waveforms and the synthetics produce an over-determined system of linear equations of the form, $A x=B$, where $A$ and $B$ are matrices concerning the joined elementary synthetics and teleseismic waveforms, respectively, $x$ is the solution vector including dislocation weights to be given at each subfault so that the final synthetics fit well the original data. The solution revealed from these matrices is not always stable and several constraints are needed which are well analyzed and explained. ${ }^{19,21}$ Usually two constraints are used, the moment minimization and smoothing. For the first earthquake of $M_{w} 6.1$ a fault plane striking NE-SW of $35 \mathrm{~km}$ in length and 20 $\mathrm{km}$ in width (Figure 7) was discretized by 108 subfaults, 18 along strike and 6 along dip. The surface edge of the fault starts at $7 \mathrm{~km}$ depth from the Earth's surface, while the down deep edge is at $27 \mathrm{~km}$ depth, the relocated hypocenter fixed at $16 \mathrm{~km}$ depth and at a distance of 11 $\mathrm{km}$ from the SW (left) edge of the fault plane. Several rupture front velocities were tested. The fixed velocity value for rupture propagation of $3 \mathrm{~km} / \mathrm{s}$ produced the best fit between data and synthetics. Six time windows with 0.8 $\mathrm{s}$ time lag duration for each one were used (Figure 7). All of the different models revealed the same slip scenario with the downward evolution of the rupture. The time evolution of slip along the fault plane (Figure 7) is presented using nearly $2.3 \mathrm{~s}$ intervals. This earthquake had a complex source time function with nearly $62 \mathrm{~cm}$ maximum slip with source duration of

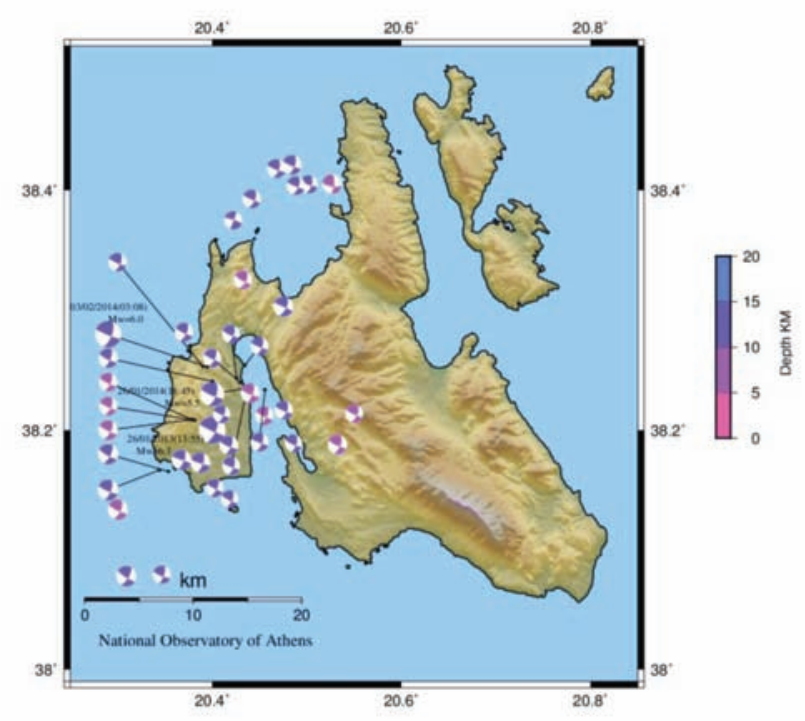

Figure 6. Focal mechanisms of the Cephalonia 2014 earthquakes listed in Appendix (for more details see in the text). 
12 s. A small slip patch also appears at the northern part of the fault which is possibly related with the small cluster at the north part of the aftershock cloud. Most of the slip is concentrated on a $13 \times 9 \mathrm{~km}$ fault rupture. For the third strong earthquake $\left(M_{w} 6.0\right)$ of 3 February 2014 a fault plane striking NE-SW of $35 \mathrm{~km}$ in length and $18 \mathrm{~km}$ in width (Figure 8 ) was discretized by 108 subfaults, 18 along strike and 6 along dip. The surface edge of the fault starts at the Earth's surface, while the down deep edge is at $18 \mathrm{~km}$ depth. The relocated hypocenter was fixed at $5 \mathrm{~km}$ depth and at a distance of $11 \mathrm{~km}$ from the left edge of the fault plane. After testing several rupture front velocities it was found that the fixed velocity value for rupture propagation of $2.7 \mathrm{~km} / \mathrm{s}$ produced the best fit between data and synthetics. Six time windows with $0.8 \mathrm{~s}$ time lag duration for each one were used. All of the different models revealed similar slip scenarios with the upward rupture evolution.

The time evolution of slip is presented using nearly $2.1 \mathrm{~s}$ intervals. This earthquake had a simple source time function related with one big patch of slip with maximum slip nearly 45 $\mathrm{cm}$ with $10 \mathrm{~s}$ source duration. A small slip patch which appears at the northern part of the fault plane possibly is related with the small cluster at the north part of the aftershock cloud as it was also observed with the rupture process of the first strong earthquake. Most of the slip, however, is concentrated on a $12 \times 6 \mathrm{~km}$ fault rupture.

\section{Strong ground motion and the macroseismic field}

The western part of Cephalonia was damaged by both the first and third strong earthquakes. Neither damage nor ground failures was reported to have caused by the second strong earthquake of the evening of 26.1.2014. We performed post-event field surveys after the two damaging earthquakes, namely from 28 to 30 January and from 5 to 7 February, respectively. As a consequence, we obtained a clear and detailed picture of the macroseismic field that is of the impact that each one of the two seismic events had. The earthquake impact comprised damage in buildings and in infrastructure as well as several types of ground failures such as landslides, rock falls, ground cracks and liquefaction in soil.

In the next subsections we present results of our field observations regarding the seismic intensities felt and the several types of ground failures caused by the earthquakes as well as the factors that controlled the extent but also the spatial distribution of the macroseismic effects (localities reported are shown in Figure
9). Since one of the main factors was the strong ground motion, we review shortly results obtained from strong motion records. The peak ground acceleration (PGA) recorded in several localities at accelerometric stations of NOAGI (Cephalonia_20140126_preliminary_web.pdf and Cephalonia_20140203_preliminary_web.pdf both at: http://www.gein.noa. $\mathrm{gr} / \mathrm{el} / \mathrm{nea}$ ) and of ITSAK (http://www.itsak.gr /news /news/79) reached up to $0.56 \mathrm{~g}$ and 0.27 $\mathrm{g}$ in Lixouri and Sami, respectively, for the first strong earthquake. Even higher PGA's were recorded with the third earthquake, namely up to $0.77 \mathrm{~g}$ in Lixouri and $0.64 \mathrm{~g}$ in Argostoli, which are the highest PGA's recorded in Greece ever. PGA of $0.19 \mathrm{~g}$ was recorded at Sami with the third strong earthquake.

\section{Macroseismic intensities}

Damage was caused mainly in single-house buildings particularly in the town of Lixouri and less in Argostoli as well as in many villages of western Cephalonia. However, no massive building collapses were reported. No persons were killed and only very few were injured. Seismic intensities of level V or more (in EMS 12-point scale) felt in several localities of the western Cephalonia were assessed after the first earthquake. The procedure was repeated after the third strong earthquake by assigning seismic intensities in the same localities by taking carefully into account that in many buildings the damage caused by the first earthquake became worst due to the third one (Figure 10).

Seismic intensities assigned are illustrated in Figure 9. A comparison of Figure 9A and B shows that both earthquakes caused maximum seismic intensity, $I_{\max }$, in a relatively limited area comprising the Lixuri town and its extension to the north up to the villages of Ayios Dimitrios and Livadi. However, the maximum seismic intensity observed after the third strong earthquake was clearly larger than the one observed after the first earthquake that is VIII to VIII+ versus VII. The isoseismal
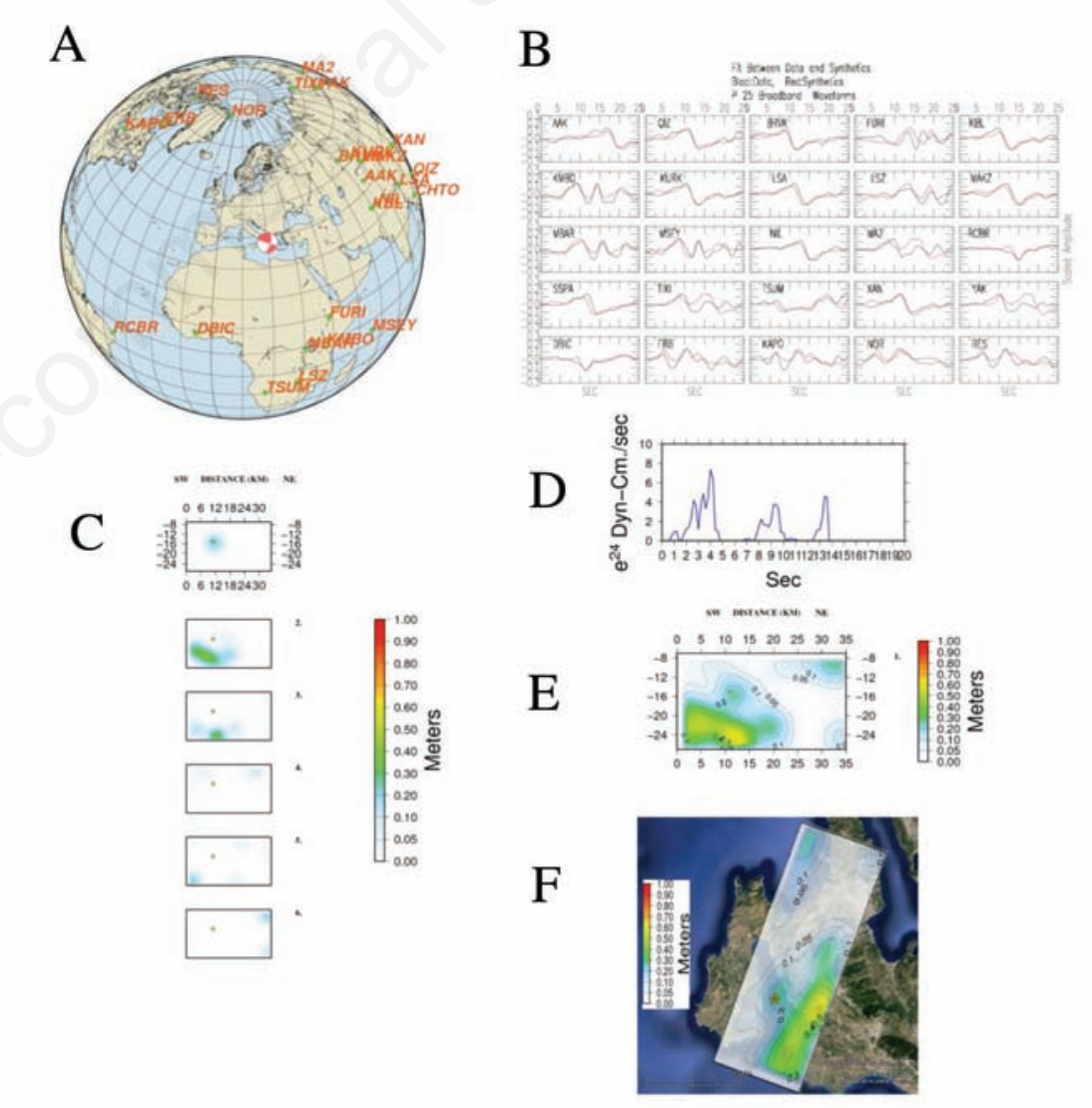

Figure 7. Rupture history of the first (26.1.2014) strong earthquake. Key: teleseismic GDSN stations around the globe used (A); observed waveforms and synthetics for the several stations (B); time evolution of slip along the fault plane in nearly $2.3 \mathrm{~s}$ intervals $(\mathrm{C})$ and of seismic moment released (D); profile of slip distribution along the fault plane (E) and its horizontal projection $(\mathrm{F})$. 
area of level $\mathrm{V}$ of the third earthquake is nearly identical with that of the first earthquake, while the large axis of the isoseismal of degree $\mathrm{V}$ of both earthquakes strikes along the NNESSW direction, which is also the strike of the preferred fault planes of the two strong earthquakes. At the northern part of the macroseismic field, however, seismic intensities felt at some localities due to the third earthquake were lower with respect to those assigned after the first strong earthquake.

\section{Ground failures}

Several types of ground failures were caused by the first and third strong earthquakes of 26.1.2014 and 3.2.2014: landslides, rock falls, ground holes, liquefaction in natural soil and in artificial embankement, extensive cracks associated with lateral spreads in grounds and roads. Landslides and rock falls very often were coexistent at the same observation spots petrographically consisting of mainly calcareous rocks. These spots as a rule are situated in quite steeply and/or very steeply sloping areas already identified and mapped by ground and satellite observations. ${ }^{29}$ Very often such steeply sloping areas are tectonically controlled by active faults. The entire area covered by ground failures caused by the first earthquake (Figure 11A) was nearly identical with the area determined by the isoseismal of level $\mathrm{V}$. The area covered by ground failures associated with the third earthquake, however, was drastically reduced (Figure 11B), a point discussed later. All ground failures observed after both
A

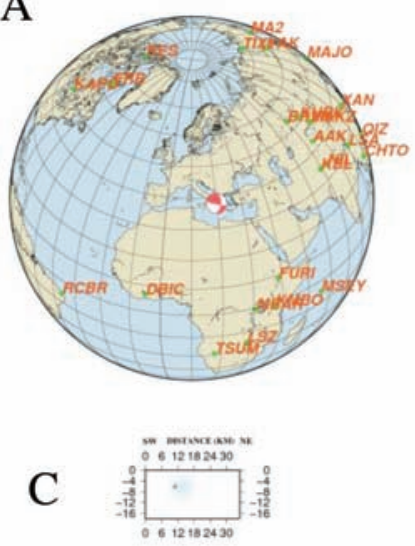

B

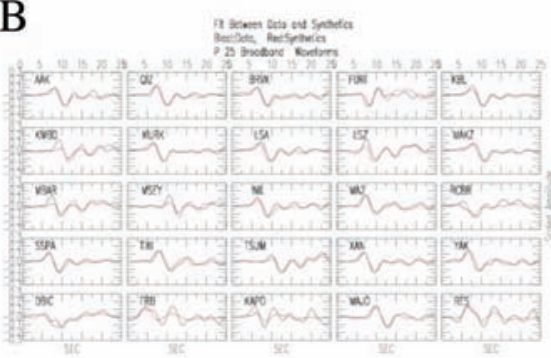

$\mathrm{D}$
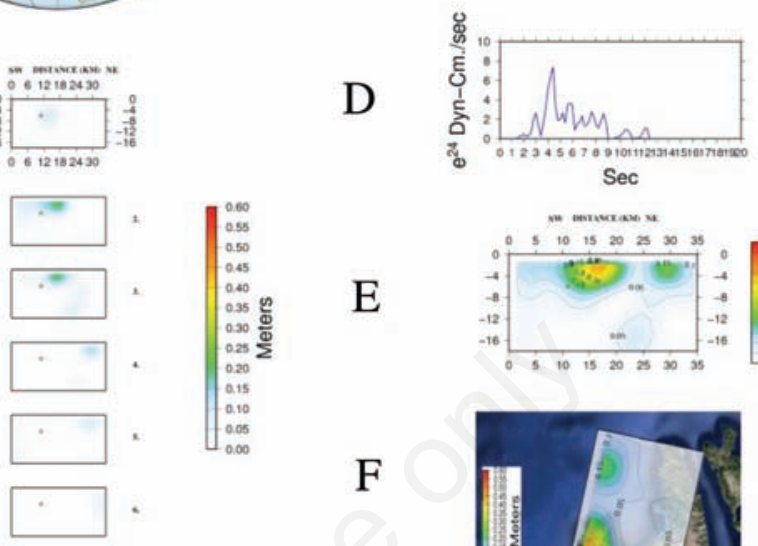

$\mathrm{E}$

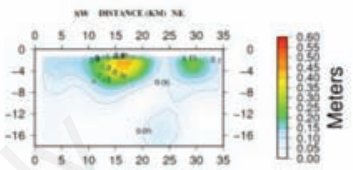

F

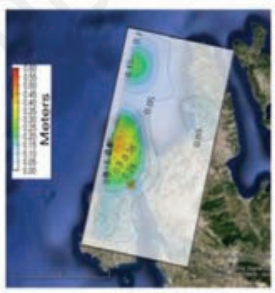

Figure 8. Rupture history of the third (3.2.2014) strong earthquake. Key: teleseismic GDSN stations around the globe used (A); observed waveforms and synthetics for the several stations (B); time evolution of slip along the fault plane in nearly $2.1 \mathrm{~s}$ intervals (C) and of seismic moment released (D); profile of slip distribution along the fault plane (E) and its horizontal projection $(\mathrm{F})$.

A

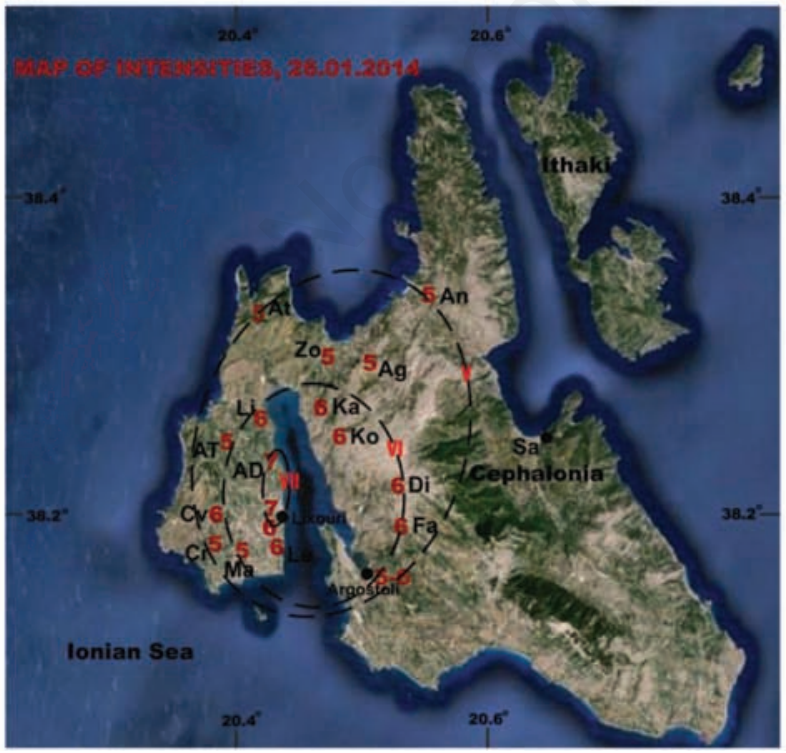

B

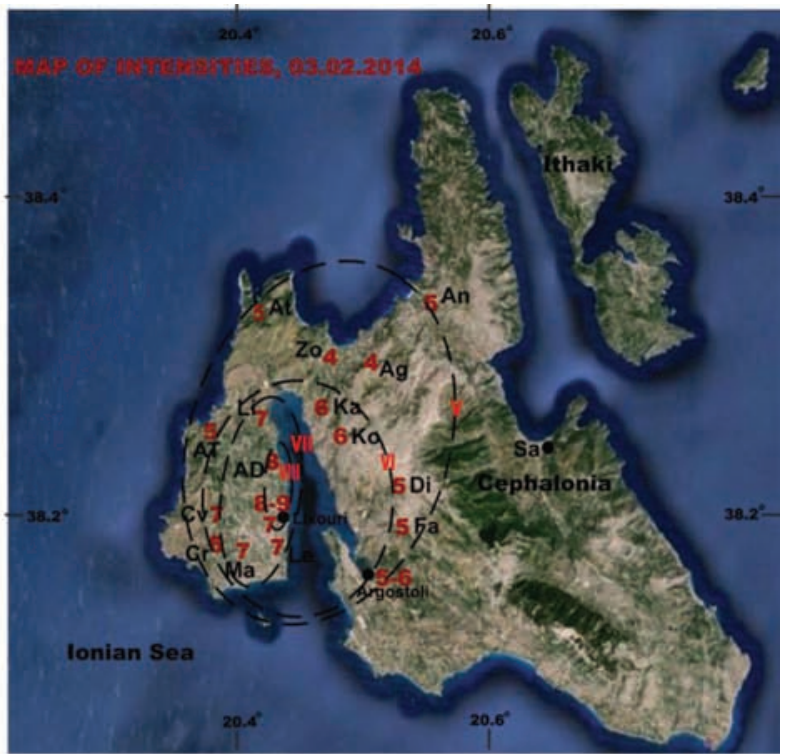

Figure 9. A) Seismic intensities (Arabic numbers) and isoseists (Roman numbers) assigned after the first strong Cephalonia earthquake of 26.1.2014. Key for localities: Ag, Agonas; An, Anomeria; At, Atheras; AD, Ayios Dimitrios; AT, Ayia Thekla; Ch, Charakas; Cv, Chavdata; Cr, Chavriata; Di, Dilinata; Fa, Faraklata; Ka, Katoxori; Ki, Kipouria; Ko, Kourouklata; Le, Lepeda; Li, Livadi; Ma, Mantzavinata; Pe, Petani; Sa, Sami; So, Soulari; Zo, Zola. B) As Figure 9A for the third (3.2.2014) strong Cephalonia earthquake. 
earthquakes fall within the limiting epicentral distances predicted by empirical relationships proposed for earthquake-induced soil liquefaction and landslides. ${ }^{30-32}$

\section{Landslides and ground cracks}

The landslide phenomena observed after the first strong earthquake cover the western side of the island in an area which is roughly elliptical trending also from NNE to SSW as the meizoseismal area does. The most important landslide events in terms of size were the ones caused in Myrtos bay and in Solari village (Figure 12) as well as along the road at the foothills of Mt Vlikatari to the SW of Myrtos (Figure 13).

The landslides caused by the third strong earthquake are concentrated only in the SW side of the island, that is in an area which is less than half the area covered by the landslides caused by the first strong earthquake. In fact, in the NW side of the island neither new landslides occurred nor landslides already triggered by the first event were moved further with the third shock.

With the first earthquake the dock in the port of Lixouri subsided in a few spots while some cracks were opened. However, abundant cracks, extensive subsidence as well as destruction of the dock accompanied by liquefaction in the artificial embankment occurred with the third earthquake (Figure 14).

\section{Rock falls and soil liquefaction}

After the first earthquake we observed many rock falls occurring as a rule in quite steeply and/or very steeply sloping areas of calcareous rocks. The entire area covered by rock falls is nearly identical with the one covered by landslides (Figure 11A). In Charakas, NW Cephalonia, a car was destroyed by rock falls (Figure 15). The third earthquake caused rock falls only along the road at the eastern side of Argostoli bay where abundant rock falls were already caused by the first strong earthquake (Figure 11).

After the first strong earthquake we observed liquefaction of sandy soil in a locality situated in the beach at the southernmost part of the Lixouri port at a distance of about $15 \mathrm{~m}$ from the seashore. The liquefaction became evident from a series of three spots of sea sand ejected along a ground fissure as long as about $6 \mathrm{~m}$ (Figure 16). A similar surface manifestation of liquefaction in soil was also observed near Argostoli. More important were the liquefaction phenomena that associated the third earthquake in the dock of the Lixouri port. We observed abundant embankment material which had ejected from many cracks opened in the dock as well as in nearby small gardens (Figure 14). These failures were accompanied by extensive subsidence and destruction in many places of the dock.

\section{Discussion}

The Cephalonia 2014 seismic sequence ruptured the western part of Cephalonia along a seismogenic structure of right-lateral strikeslip with some thrust component. This feature underlines a clear seismotectonic similarity with the Lefkada 2003 sequence that ruptured with the same mode to the NNE continuation of the Cephalonia 2014 sequence. Then, important seismotectonic implications are raised. The first regards the geometry of the CTFZ which has been suggested as comprising two main segments (Figure 1) striking offshore and parallel to the Lefkada and Cephalonia west coasts with strikes of NNESSW and NE-SW, respectively. 1,4,533 However, after that the Cephalonia 2014 earthquakes ruptured on land western Cephalonia Isl. little doubt remains that the Lefkada CTFZ segment continues to western Cephalonia. This turns to understand that the Lefkada CTFZ segment possibly branches into two segments, one rupturing onland west Cephalonia and possibly another one striking offshore west Cephalonia. This interpretation leaves open for investigation if the onland branch strikes further to offshore SW Cephalonia or not.

One may suggest that the northern part of the Cephalonia 2014 seismogenic volume acted as an asperity or barrier that prevented
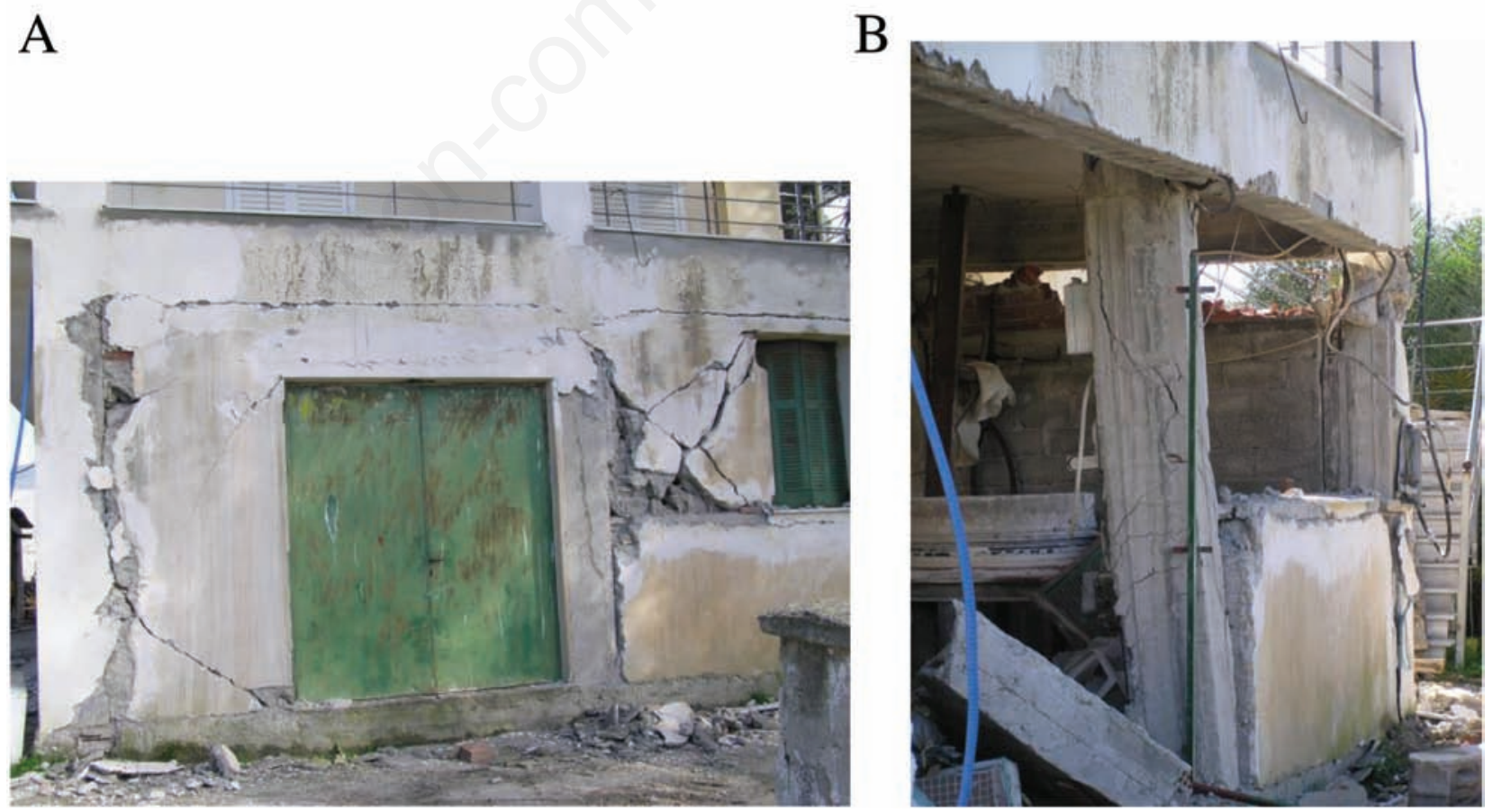

Figure 10. Example of two-storey building in Ayios Dimitrios village (see location in Figure 9) damaged by the first (A) and the third (B) Cephalonia strong earthquakes. 
the Lefkada 2003 rupture to propagate further to SSW. Besides, the Lefkada 2003 seismic sequence itself ruptured in two subsegments, the north and south ones, with an asperity of relatively small size remaining between the two ruptures. ${ }^{2,14}$ The moderate $\left(\mathrm{M}_{\mathrm{w}} 5.7\right)$ earthquake of 25.3.2007 in NW Cephalonia possibly was a first attempt of the Lefkada segment to rupture further towards SSW.

The difference in the relocated foci of the strong earthquakes of 26.1.2014 and 3.2.2014 may indicate that possibly two different subparallel faults, corresponding to the two earthquakes, were activated onland west Cephalonia. These two earthquakes help to understand better the historical seismicity of Cephalonia as well. A preliminary selection may include the strong earthquakes of 24 August 1658, 23 June 1741, 13 June 1759, 22 July 1766 and one in $1833 .{ }^{33,34}$ In fact, all these earthquakes were destructive in Paliki that is in western Cephalonia, and particularly in Lixouri. However, no damage was reported from the rest part of Cephalonia, thus having a close similarity with the 2014 strong earthquakes. Of seismotectonic interest is also the aftershock cluster that occupies the northernmost part of the relocated 2014 aftershock sequence (Figure 2). It should be reminded that in the rupture histories of both the first and third strong earthquakes a small slip patch appears at the northern part of the fault plane which geographically coincides with that cluster. On the other hand, the earthquake activity started there just a few days before the first strong earthquake, which means that this cluster should be seen not only as part of the rupture process but also as a possible triggering factor of the strong earthquake activity that started on 26.1.2014. This is a point that certainly deserves further investigation. For understanding the configuration of the macroseismic fields of both the first and third strong earthquakes of special value is not only the role of soil conditions but also of other factors, including the rupture process and the strong ground motion. From Figure 9 it results that the meizoseismal areas of the two strong earthquakes are geographically coincident, regardless the maximum intensity observed in each one of the two areas. This underlines the critical role of the soft ground conditions in the areas of Lixouri town and of the villages of Ayios Dimitrios and Livadi, which in both cases controlled geographically the meizoseismal area. In fact, the ground material prevailing in the meizoseismal area consists of thick Lower Pleistocene formations of marls where calcareous sand layers are interbeded. In such soil conditions situated in the near-field domain one may expect drastic amplification of the ground motion caused by the high PGAs recorded.

The important role of the rupture process for the maximum seismic intensity configuration comes also out from that the PGA caused by the third earthquake was larger than that caused by the first earthquake. In fact, this is an expected difference given that the third earthquake ruptured upwards and at much shallower depths, in contrast to the rupture at deeper depths and downwards during the first earthquake. On the other hand, it should not escape our attention that the buildings became highly vulnerable after the damage caused by the first earthquake and this certainly favored even higher damage to be caused by the third earthquake.

The isoseismal area of level $\mathrm{V}$ of the third earthquake is nearly identical with that of the first earthquake, while the large axis of the isoseismal $\mathrm{V}$ of both earthquakes strikes along the NNE-SSW direction, which is nearly the strike of the preferred fault planes of the two strong earthquakes. The coincidence of the two isoseismal areas of level $\mathrm{V}$ implies that the seismic intensities observed in localities away from the meizoseismal area were controlled rather by the strong motion than by site conditions.

In the northern side of the isoseismal area of level $\mathrm{V}$, that is in relatively large epicentral distances, in some localities the seismic intensities felt due to the third event were reduced with respect to the intensities caused by the first event. The faster attenuation of the seis-
A

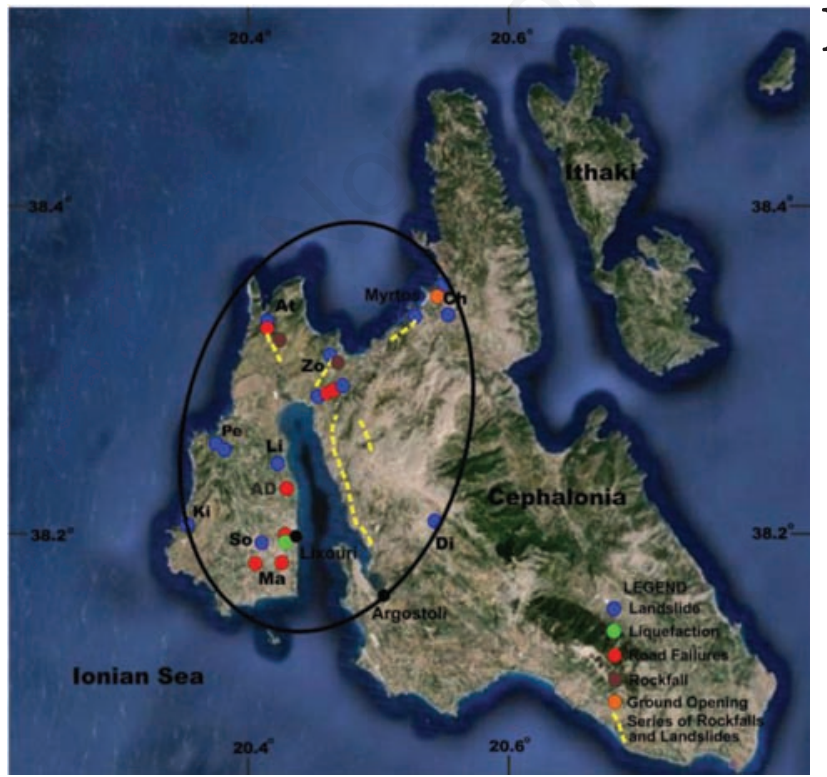

B

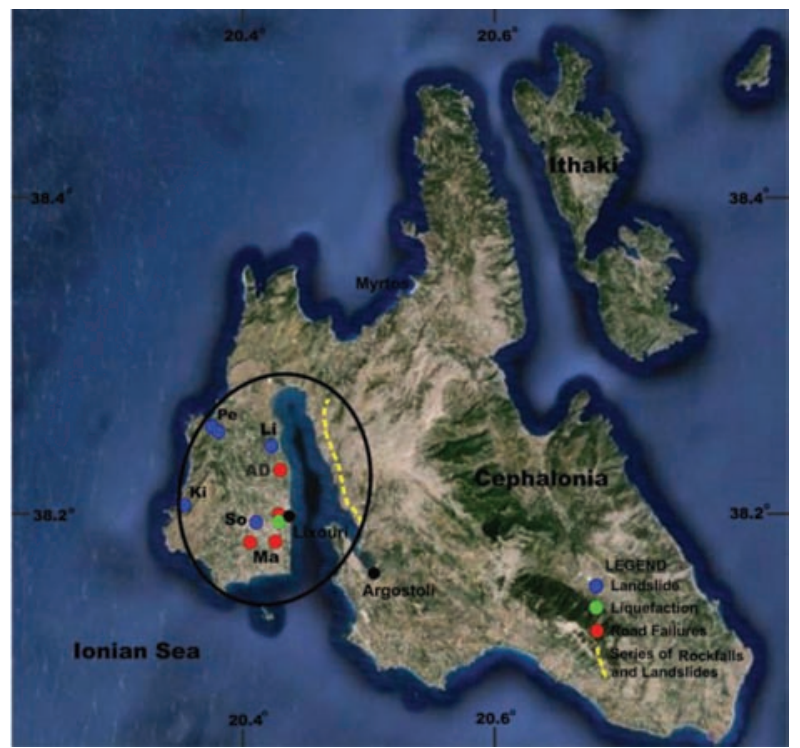

Figure 11. A) Ground failures observed in Cephalonia after the first strong earthquake of 26.1.2014. The ground failures area is nearly identical with the aftershock area. For the localities key see Figure 9A. B) Ground failures observed in Cephalonia after the third strong earthquake of 3.2.2014. The ground failures area is drastically reduced as compared to that of 26.1.2014 (Figure 11A). For the localities key see Figure 9A. 
mic intensities in the third earthquake is consistent with the faster attenuation of the PGAs as one may conclude from the smaller PGA recorded in Sami station during the third earthquake as compared to the PGA recorded in the same station during the first earthquake. This may have also controlled the geographical distributions of landslides. In fact, the first earthquake triggered landslides in the entire western Cephalonia. On the contrary, the landslides caused by the third earthquake are limited only in the SW side of the island. The ground acceleration, which away from the meizoseismal area was lower during the third earthquake as compared to that of the first earthquake, very possibly controlled the landslide geographical distribution. We may not rule out, however, that this pattern of geographical distribution is due to that the landslide potential in NW Cephalonia was reduced after the first episode.

In the NW side of Cephalonia the landslides and rock falls occurred as a rule in localities characterized by steep or very steep slopes of calcareous rocks. However, the area covered by ground failures associated with the third earthquake was drastically reduced (Figure 11B) which is an evidence that the triggering of ground failures was controlled not only by the local lithology and geomorphology but also by the strong ground motion.

\section{Conclusions}

The conclusions of this first report on the January-February 2014 strong earthquake sequence in Cephalonia can be summarized as follows: i) From the relocated aftershock sequence it was found that the seismogenic layer strikes NNE-SSW with length $L=35 \mathrm{~km}$, maximum width up to $10 \mathrm{~km}$ and thickness of $15 \mathrm{~km}$; ii) Two aftershock spatial clusters were revealed at north $\left(L_{l} \sim 10 \mathrm{~km}\right)$ and at south $\left(L_{2} \sim 25 \mathrm{~km}\right)$. However, there is no temporal correlation between the two clusters and the strong earthquakes of 26.1.2014 and 3.2.2014; iii) The Omori-law showed relatively slow aftershock decay as compared to other aftershock sequences in Greece. The aftershock $b$ value was found anomalously low with respect to that of the Cephalonia background seismicity but this result needs further examination with a better earthquake catalogue; iv) Fault plane solutions produced by moment tensor inversions indicated that the seismotectonics of both strong shocks and the aftershocks $\left(M_{w}>=4.0\right)$ were associated with dextral strike-slip faulting with some thrust component and preferred NNE-SSW fault planes. The average fault plane parameters obtained for the three largest events are: strike $21( \pm 2)^{0}$, dip $65.5( \pm 3)^{0}$, rake $173( \pm 3)^{0}$; v) Teleseismic records inverted to account for rupture histories showed that the strong earthquake of 26.1.2014 $\left(\mathrm{M}_{\mathrm{w}} 6.0\right.$, focal depth $\left.\mathrm{h}=16 \mathrm{~km}\right)$ had a complex source time function with $62 \mathrm{~cm}$ maximum slip, source duration of $\sim 12 \mathrm{~s}$ and downwards rupture, while most of the slip was concentrated on a $13 \times 9 \mathrm{~km}$ fault rupture; vi) The strong earthquake of 3.2.2014 $\left(\mathrm{M}_{\mathrm{w}} 5.9, \mathrm{~h}=5 \mathrm{~km}\right)$ had a relatively simple source time function related with one big patch of maximum slip 45 $\mathrm{cm}$ and $10 \mathrm{~s}$ source duration. The rupture was directed upwards and most of the slip was concentrated on a $12 \times 6 \mathrm{~km}$ fault rupture; vii) The significantly larger $\mathrm{PGA}=0.77 \mathrm{~g}$ recorded with the strong earthquake of 3.2.2014 as compared to the $\mathrm{PGA}=0.56 \mathrm{~g}$ recorded with the first earthquake of 26.1.2014 could be interpreted by the mode (upward) of rupture and the significantly shallower depth of the 3.2.2014 earthquake; viii) The two strong earthquakes caused considerable damage. Both had their meizoseismal areas in Lixouri town and the nearby villages with maximum seismic intensity reaching level VII and VIII to VIII+ (EMS) with the first and the second earthquake, respectively. In both earthquakes the meizoseismal area very likely was controlled mainly by soft soil conditions. Different rupture histories and the increased building vulnerability after the damage caused by the first shock of 26.1.2014 may account for the larger intensity observed after the shock of 3.2.2014. The isoseismal of level $\mathrm{V}$ for both earthquakes is nearly coincident with the aftershock zone; ix) Both earthquakes caused also several types of ground failures: landslides, soil liquefaction, rock falls, and ground cracks associated with

A
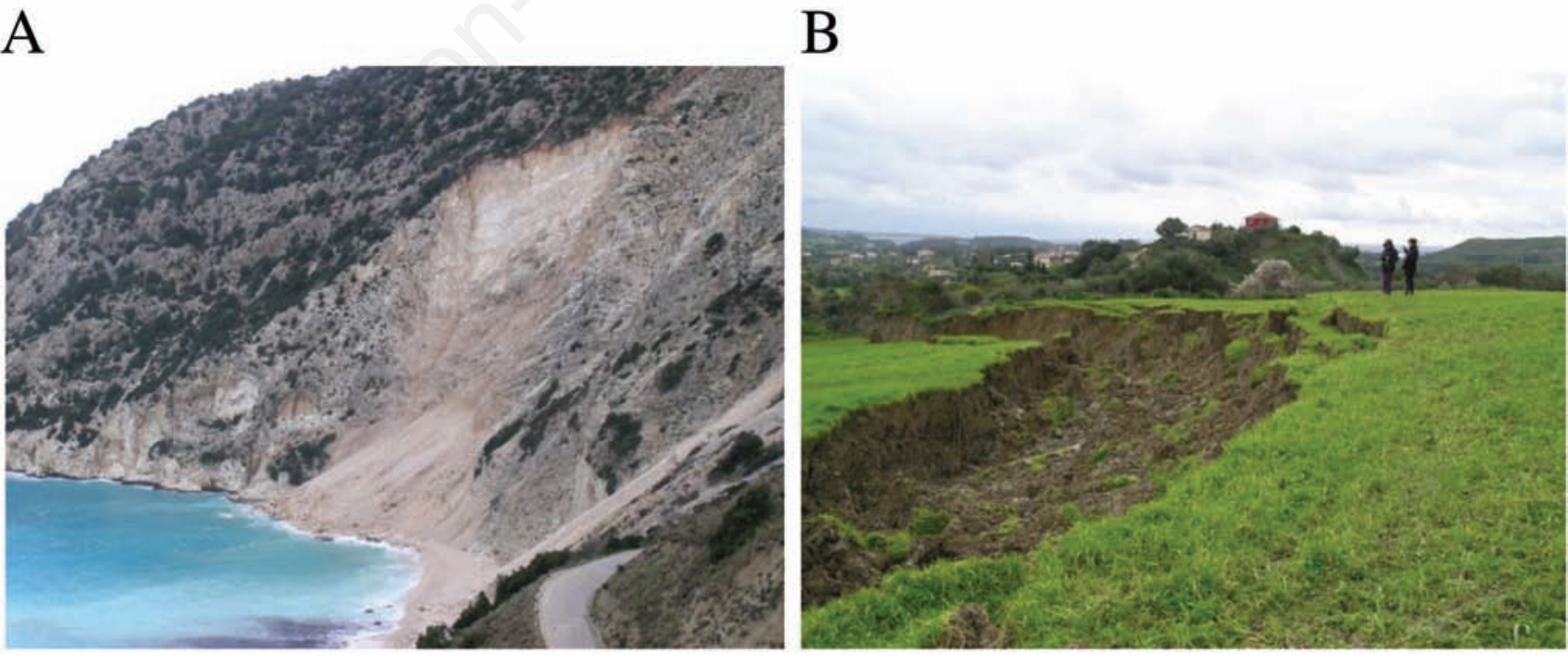

Figure 12. Landslides in calcareous rocks caused in Myrtos Bay (NW Cephalonia) with the first strong earthquake of 26.1.2014 (A), and in Neogene marls near village Solari (SW Cephalonia) initially triggered with the first strong earthquake, as it widened by the third strong earthquake of 3.2.2014 (B). 


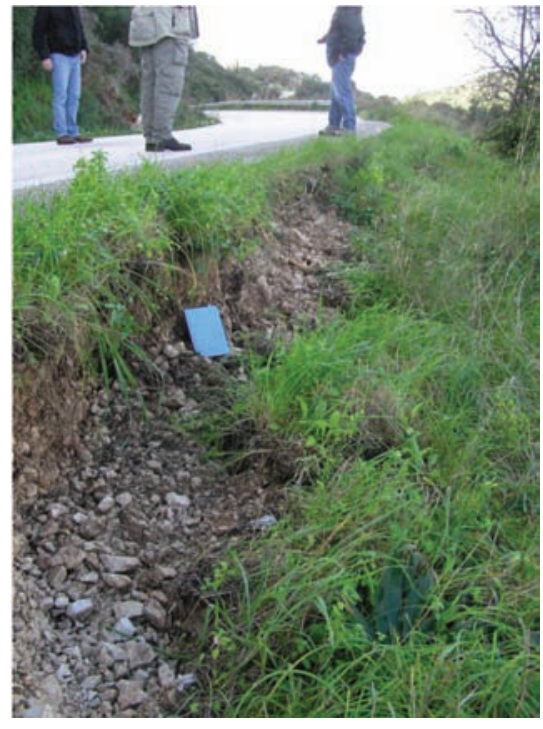

Figure 13. Landslide caused downslope in the road at the foothills of Mt Vlikatari to the SW of Myrtos, NW Cephalonia, with the first strong earthquake of 26.1.2014.
A

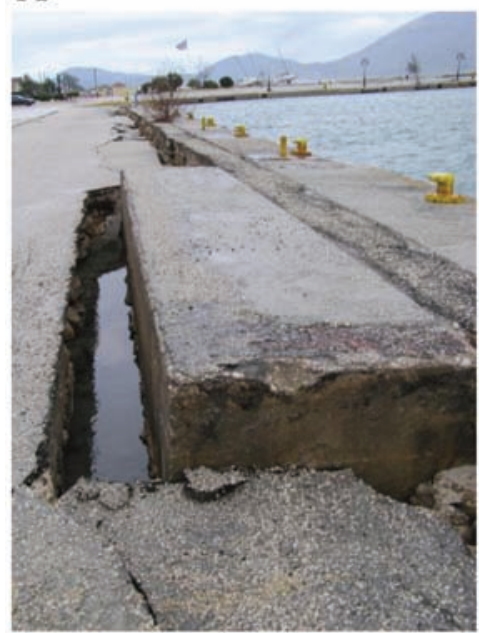

B

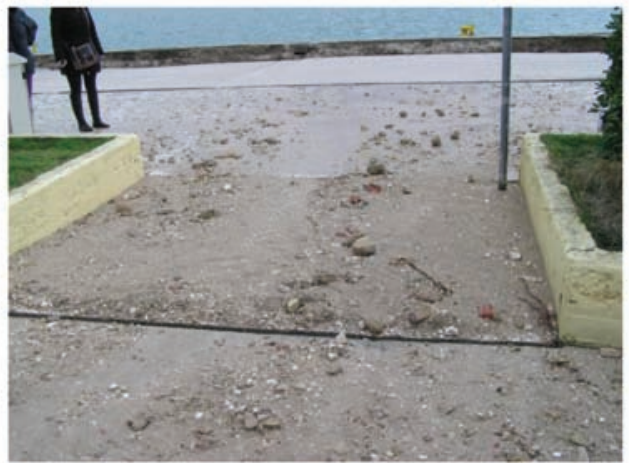

Figure 14. Failures observed at the dock of the Lixouri port after the third strong earthquake of 3.2.2014. Extensive cracking and subsidence (A) and artificial embankment material ejected from a dock crack due to liquefaction (B).
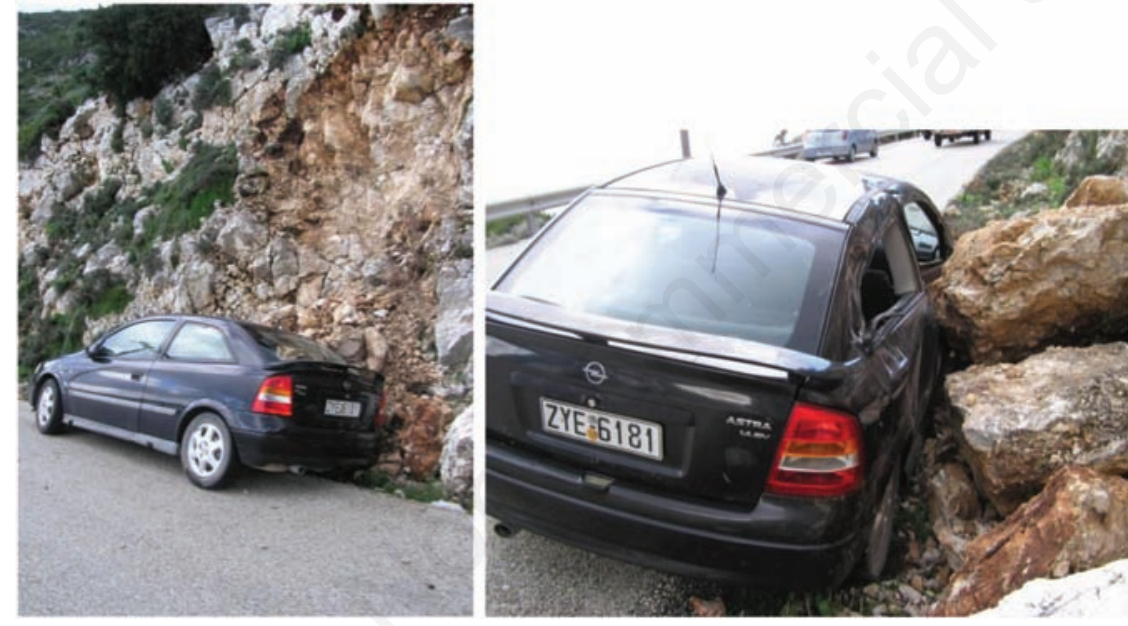

Figure 15. A car crashed by rock-falls caused in Charakas (NW Cephalonia) due to the first strong earthquake.

lateral spreads. The area of ground failures caused by the first earthquake nearly coincides with the aftershock zone. However, the ground failures area of the second earthquake was nearly half of that of the first earthquake, which is consistent with the faster attenuation of ground acceleration away from the meizoseismal area caused by the second earthquake with respect to the first one; $x$ ) The JanuaryFebruary 2014 earthquakes ruptured western
Cephalonia Isl. at the SSW-wards continuation of the Lefkada segment of the CTFZ. Therefore, we supported the need to revise the CTFZ geometry in the sense that the Lefkada CTFZ segment does not terminates offshore NW Cephalonia but extends towards SSW in western Cephalonia. Then, the geometry of the Cephalonia segment of the CTFZ remains in doubt and certainly needs further investigation.

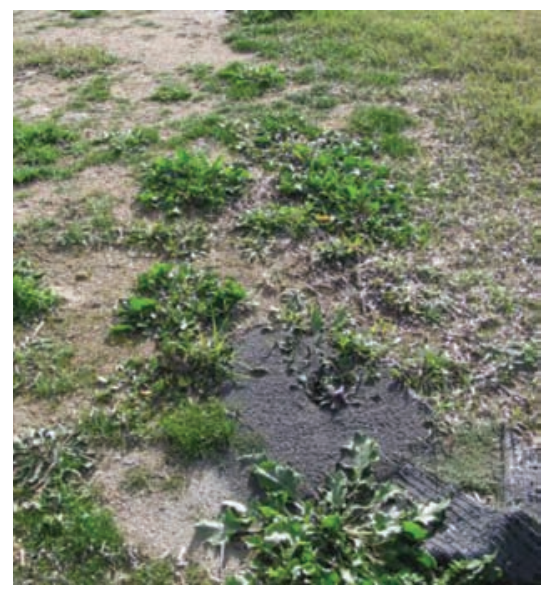

Figure 16. Spots of sea sand that was ejected during soil liquefaction caused along a ground crack opened to the south of Lixouri port with the first strong earthquake.

\section{References}

1. Scordilis EM, Karakaisis GF, Karakostas BG, et al. Evidence for transform faulting in the Ionian Sea: the Cephalonia island earthquake sequence of 1983. Pure Appl Geophys 1985;123:388-97.

2. Papadopoulos GA, Karastathis VK, Ganas A, et al. The Lefkada, Ionian Sea (Greece), 
shock (Mw 6.2) of 14 August 2003: evidence for the characteristic earthquake from seismicity and ground failures. Earth Planets Space 2003;55:713-8.

3. Papazachos BC, Papazachou CB. The earthquakes of Greece. Thessaloniki: Zitti Ed.; 1997.

4. Kahle H-G, Müller MV, Geiger A, et al. The strain field in northwestern Greece and the Ionian Islands: results inferred from GPS measurements. Tectonophysics 1995;249:41-52.

5. Louvari E, Kiratzi AA, Papazachos BC. The Cephalonia transform fault and its extension to western Lefkada Island (Greece). Tectonophysics 1999;308:223-36.

6. Papadopoulos GA, Skafida HG, Vassiliou IT. Non-linearity of the magnitude-frequency relation in the Hellenic arc-trench system and the characteristic earthquake model. J Geophys Res 1993;98:17737-44.

7. Sachpazi M, Hirn A, Clement C, et al. Western Hellenic subduction and Cephalonia transform: local earthquakes and plate transport and strain. Tectonophysics 2000;319:301-19.

8. Laigle M, Sachpazi M, Hirn A. Variation of seismic coupling with slab detachment and upper plate structure along the western Hellenic subduction zone. Tectonophysics 2004;391:85-95.

9. Karastathis V, Koukouvelas I, Ganas A, et al. The strong Mw6 earthquake of 26th January 2014 in Cephalonia island, Ionian Sea, Greece: a first report. Geophys. Res. Abstr. 2014, 16: EGU 2014-1700, Europ. Geosci. Union General Assembly, 2014.

10. Haslinger F, Kissling E, Ansorge J, et al. 3D crustal structure from local earthquake tomography around the Gulf of Arta (Ionian region, NW Greece). Tectonophysics 1999;304:201-18.

11. Omori F. On the aftershocks of earthquakes. J Coll Sci Imp Univ Tokyo 1894;7:111-200.

12. Utsu T. A statistical study of the occurrence of aftershocks. Geophysical Magazine 1961;30:521-605.

13. Gutenberg B, Richter C. Frequency of earthquakes in California. B Seismol Soc Am 1944;34:185-188.
14. Benetatos C, Kiratzi A, Roumelioti Z, et al. The 14 August 2003 Lefkada Island (Greece) earthquake: Focal mechanisms of the mainshock and of the aftershock sequence. J Seismol 2005;9:171-90.

15. Institute of Geodynamics of the National Observatory of Athens (NOA-IG). Manual solution for event evman070325135758; 2007. Available from: http://bbnet.gein. noa.gr/alerts_manual/2007/03/evman0703 25135758_info.html

16. Randal GE. Efficient calculation of complete differential seismograms for laterally homogeneous earth models. Geophys J Int 1994;118:245-54.

17. Kennett BNL. Seismic wave propagation in Stratified Media. Cambridge: Cambridge University Press; 1983.

18. Konstantinou KI, Melis N, Boukouras K. Routine regional moment tensor inversion for earthquakes in the Greek Region: The National Observatory of Athens (NOA) database (2001-2006). Seismol Res Lett 2012;81:750-60.

19. Hartzell SH, Heaton TH. Inversion of strong ground motion and teleseismic waveform data for the fault rupture history of the 1979 Imperial Valley, California, earthquake. B Seismol Soc Am 1983;73:1553-83.

20. Hartzell S, Langer C. Importance of model parameterization in Finite fault inversions: application to the $1974 \mathrm{Mw}$ 8.0 Peru Earthquake. J Geophys Res 1993;98B12:22123-34.

21. Hartzell S, Pengcheng L, Mendoza C. The 1994 Northridge, California earthquake: investigation of rupture velocity, risetime and high-frequency radiation. J Geophys Res 1996;101:20091-108.

22. Mendoza C, Hartzell S. Fault-slip distribution of the 1995 Colima-Jalisco, Mexico, Earthquake. B Seismol Soc Am 1999;89:1338-44.

23. Sekiguchi H, Iwata T. Rupture process of the 1999 Koaceli, Turkey, earthquake estimated form strong-motion waveforms. B Seismol Soc Am 2002;92:300-11.

24. Ji C, Wald DJ, Helmberger DV. Source description of the 1999 Hector Mine, California earthquake; Part I: Wavelet domain inversion theory and resolution analysis. B Seismol Soc Am 2002;92:1192207.

25. Yuji Y, Yukitoshi F. Introduction of uncertainty of Green's function into waveform inversion for seismic source processes. Geophys J Int 2011;186:711-20.

26. Wald DJ, Heaton TH. Spatial and temporal distribution of slip for the 1992 Landers, California, earthquake. B Seismol Soc Am 1994;84:668-91.

27. Langston CA, Helmberger DV. A procedure for modeling shallow dislocation sources. Geophys J Royal Astron Soc 1975;42:11730.

28. Heaton TH. The 1971 San Fernando earthquake: a double event? B Seismol Soc Am 1982;72:2037-62.

29. Poscolieri M, Lagios E, Gregori GP. Crustal stress and seismic activity in the Ionian archipelago as inferred by satellite- and ground based observations, Kefallinia, Greece. In: Cello G, Malamud BD, eds. Fractal analysis for natural hazards. The Geological society of London 2006. Special Publ. no. 261. London: Geological Society; 2006. pp 63-78.

30. Papadopoulos GA, Lefkopoulos G. Magnitude-distance relations for liquefaction in soil from earthquakes. B Seismol Soc Am 1993;83:925-38.

31. Papadopoulos AG, Plessa A. Magnitudedistance relations for earthquake-induced landslides in Greece. Engine Geol 2000;58:377-86.

32. Papathanassiou G, Pavlides S, Christaras B, Pitilakis K. Liquefaction case histories and empirical relations of earthquake magnitude versus distance from the broader Aegean region. J Geodyn 2005;40:257-78.

33. Papazachos BC, Papazachou C. The earthquakes of Greece. Thessaloniki: Ziti editions; 2003. [In Greek].

34. Ambraseys N. Earthquakes in the Mediterranean and Middle East, A multidisciplinary study of seismicity up to 1900 . Cambridge, UK: Cambridge University Press; 2009. 